\title{
Regional Localization of Suspensor mRNAs during Early Embryo Development
}

\author{
Koen Weterings, ${ }^{\mathrm{a}, 1,2}$ Nestor R. Apuya, ${ }^{\mathrm{a}, 1,3}$ Yuping $\mathrm{Bi},{ }^{a}$ Robert L. Fischer, ${ }^{\mathrm{b}}$ John J. Harada, ${ }^{\mathrm{c}}$ and \\ Robert B. Goldberg ${ }^{\mathrm{a}, 4}$ \\ a Department of Molecular, Cell, and Developmental Biology, University of California, Los Angeles, California 90095-1606 \\ ${ }^{b}$ Department of Plant and Microbial Biology, University of California, Berkeley, California 94720 \\ c Section of Plant Biology, Division of Biological Sciences, University of California, Davis, California 95616
}

\begin{abstract}
We investigated gene activity within the giant embryos of the scarlet runner bean (Phaseolus coccineus) to gain understanding of the processes by which the apical and basal cells become specified to follow different developmental pathways after division of the zygote. We identified two mRNAs, designated G564 and C541, that accumulate specifically within the suspensor of globular-stage embryos. G564 mRNA accumulates uniformly throughout the suspensor, whereas C541 mRNA accumulates to a higher level within the large basal cells of the suspensor that anchor the embryo to the surrounding seed tissue. Both G564 and C541 mRNAs begin to accumulate shortly after fertilization and are present within the two basal cells of embryos at the four-cell stage. In contrast, at the same stage, these mRNAs are not detectable within the two descendants of the apical cell. Nor are they detectable within cells of the embryo sac before fertilization, including the egg cell. We used a G564/ $\beta$-glucuronidase reporter gene to show that the G564 promoter is activated specifically within the basal region and suspensor of preglobular tobacco embryos. Analysis of the G564 promoter identified a sequence domain required for transcription within the suspensor that contains several copies of a conserved motif. These results show that derivatives of the apical and basal cells transcribe different genes as early as the four-cell stage of embryo development and suggest that the apical and basal cells are specified at the molecular level after division of the zygote.
\end{abstract}

\section{INTRODUCTION}

In most higher plants, the first division of the zygote is asymmetric, giving rise to two daughter cells differing in size and developmental fate (Johri, 1984; Raghavan, 1986; West and Harada, 1993; Goldberg et al., 1994; Kaplan and Cooke, 1997; Laux and Jurgens, 1997). The small terminal, or apical cell, is cytoplasmically dense and differentiates into the embryo proper containing one or two cotyledons and an axis with shoot and root meristems. By contrast, the large, highly vacuolate basal cell differentiates into the hypophysis and suspensor. The hypophysis contributes to the formation of the root meristem within the embryo proper (van Den Berg et al., 1998). The suspensor, on the other hand, is a terminally differentiated embryonic region that anchors the embryo proper to the surrounding maternal tissue,

\footnotetext{
1 These authors contributed equally to this work.

${ }^{2}$ Current address: Department of Experimental Botany, University of Nijmegen, 6525 ED Nijmegen, The Netherlands.

${ }^{3}$ Current address: Ceres, Inc., 3007 Malibu Canyon, Malibu, CA 90265.

${ }^{4}$ To whom correspondence should be addressed. E-mail bobg@ucla. edu; fax 310-825-8201.

Article, publication date, and citation information can be found at www.aspb.org/cgi/doi/10.1105/tpc.010326.
}

serves as a conduit for nutrients and growth regulators supporting embryo proper development, and degenerates by the end of embryogenesis (Yeung and Clutter, 1979; Natesh and Rau, 1984; Walthall and Brady, 1986; Yeung and Meinke, 1993; Schwartz et al., 1997). What causes the apical and basal cells to become specified and follow different developmental pathways is not known.

The suspensor provides an excellent opportunity to use molecular biological approaches to understand how the zygote gives rise to daughter cells with distinct developmental fates. It is highly differentiated and contains cells that are direct clonal descendants of the basal cell and, ultimately, the basal region of the egg (Yeung and Meinke, 1993; Goldberg et al., 1994; Schwartz et al., 1997). Fully developed Arabidopsis and tobacco suspensors, for example, are only three to four cell divisions removed from the basal cell (Soueges, 1920; Mansfield and Briarty, 1991). It is possible, therefore, that the mechanisms regulating suspensor-specific gene expression are linked directly to the processes that specify the developmental fate of the basal cell. Understanding how suspensor gene expression is regulated should provide insight into the molecular mechanisms that specify the fate of the basal cell. 
We have used the giant embryos of the scarlet runner bean to investigate the processes that regulate suspensor differentiation. Because of their large size, scarlet runner bean embryos have been used classically to study the molecular and physiological processes that occur during the early postfertilization stages of embryo development (Walbot et al., 1972a, 1972b; Sussex et al., 1973; Clutter et al., 1974; Nagl, 1974; Yeung, 1980). Scarlet runner bean suspensors are $\sim 100$-fold larger than are the suspensors of either Arabidopsis or tobacco, and they contain polytene chromosomes analogous to those in Drosophila salivary glands (Nagl, 1974; Yeung and Meinke, 1993). These polytene chromosomes exhibit specific puffs in response to different physiological conditions and mark regions of gene activity (Nagl, 1974). Scarlet runner bean suspensors can be separated from embryo proper regions by microdissection with relative ease at the preglobular and globular stages (Walbot et al., 1972a; Sussex et al., 1973; Clutter et al., 1974; Nagl, 1974; Yeung, 1980) and represent a powerful system to use genomics to uncover genes that are active at the earliest stages of embryogenesis.

In this article, we present experiments that identified two scarlet runner bean mRNAs, designated C541 and G564, that accumulate specifically within the suspensor of globular-stage embryos. These mRNAs are not detectable before fertilization. At the preglobular, or four-cell, stage, both C541 and G564 mRNAs are present in the two basal cells, but they are absent from the two descendants of the apical cell. Expression analysis of a chimeric G564/ $\beta$-glucuronidase (GUS) marker gene in transgenic tobacco embryos showed that the G564 promoter is activated specifically within the basal region and suspensor during preglobular stages of embryo development, reflecting the G564 mRNA accumulation pattern in scarlet runner bean embryos. Deletion analysis of the G564 promoter indicated that sequences between -921 and -662 that contain multiple copies of a 10-bp motif are required for transcription within the suspensor. These results show that derivatives of the apical and basal cells transcribe different genes as early as the four- cell stage of embryogenesis and suggest that the apical and basal cells are specified at the molecular level after asymmetric division of the zygote.

\section{RESULTS}

\section{Giant Scarlet Runner Bean Suspensor Forms Early in Embryo Development}

We characterized the early stages of scarlet runner bean embryo development to link these stages to morphological markers of the developing seed and to provide a time framework for investigating suspensor-specific gene expression in the cultivar that we used (Hammond's Dwarf Red Flower; see Methods). Table 1 and Figures 1A to 1D and Figures $1 \mathrm{l}$ to $1 \mathrm{~K}$ summarize the morphological characteristics of the unfertilized ovule (ol) and developing seed from 0 days after pollination (DAP) until maturity at 35 DAP. From the mature unfertilized ovule until 7 DAP, the seed length increased from 0.75 to 2 to $4 \mathrm{~mm}$ and the seed gradually adopted a green color (Figures $1 \mathrm{~A}$ to $1 \mathrm{D}$ and 1I, Table 1). At $11 \mathrm{DAP}$, the seed began to acquire red pigmentation in the area contiguous to the hilum region (hl) (Figure 1J, Table 1) and the red color gradually spread and covered the entire seed by 20 to 25 DAP (Figure 1K, Table 1). At 25 DAP, the seed length had increased to $15 \mathrm{~mm}$ (Table 1). At 35 DAP, the mature dry seed had a purple seed coat with magenta streaks near the hilum and was $20 \mathrm{~mm}$ in length (Table 1).

We characterized the embryonic stages corresponding to seeds at different DAP from micrographs of longitudinal sections of the micropylar region ( $\mathrm{mr}$ ) containing the embryo. In the unfertilized ovule, the egg cell $(\mathrm{ec})$ was identified from the orientation of its nucleus and cytoplasm-dense region toward the chalaza and its vacuolated region toward the micropyle (Figure 1E). These cytological features were inverted in the adjacent synergids (sy) (Figure 1E). The egg cell and

Table 1. Description of Scarlet Runner Bean Seed Developmental Stages

\begin{tabular}{|c|c|c|c|c|}
\hline Stage & DAP & $\begin{array}{l}\text { Suspensor } \\
\text { Length }(\mu \mathrm{m})\end{array}$ & $\begin{array}{l}\text { Seed } \\
\text { Length }(\mathrm{mm})\end{array}$ & Seed Color \\
\hline Ovule & 0 & - & $<0.75$ & White \\
\hline Proembryo & 1 to 4 & $<50$ to 250 & 0.75 to 1.5 & Pale green \\
\hline Globular & 5 to 9 & 320 to 600 & 2 to 4 & Green \\
\hline Heart & 10 to 12 & 700 to 900 & 4.5 to 6 & $\begin{array}{l}\text { Green with red pigment } \\
\text { contiguous to the hilum }\end{array}$ \\
\hline Early cotyledon & 13 to 17 & $\sim 1000$ & 7 to 9 & $\begin{array}{l}\text { Green with heavy red pigment in } \\
\text { the area surrounding the hilum }\end{array}$ \\
\hline Late cotyledon & $\sim 25$ & $N D^{a}$ & $\sim 15$ & Scarlet red \\
\hline Mature & $\sim 30$ to 35 & $N^{a}$ & $\sim 20$ & Purple \\
\hline
\end{tabular}



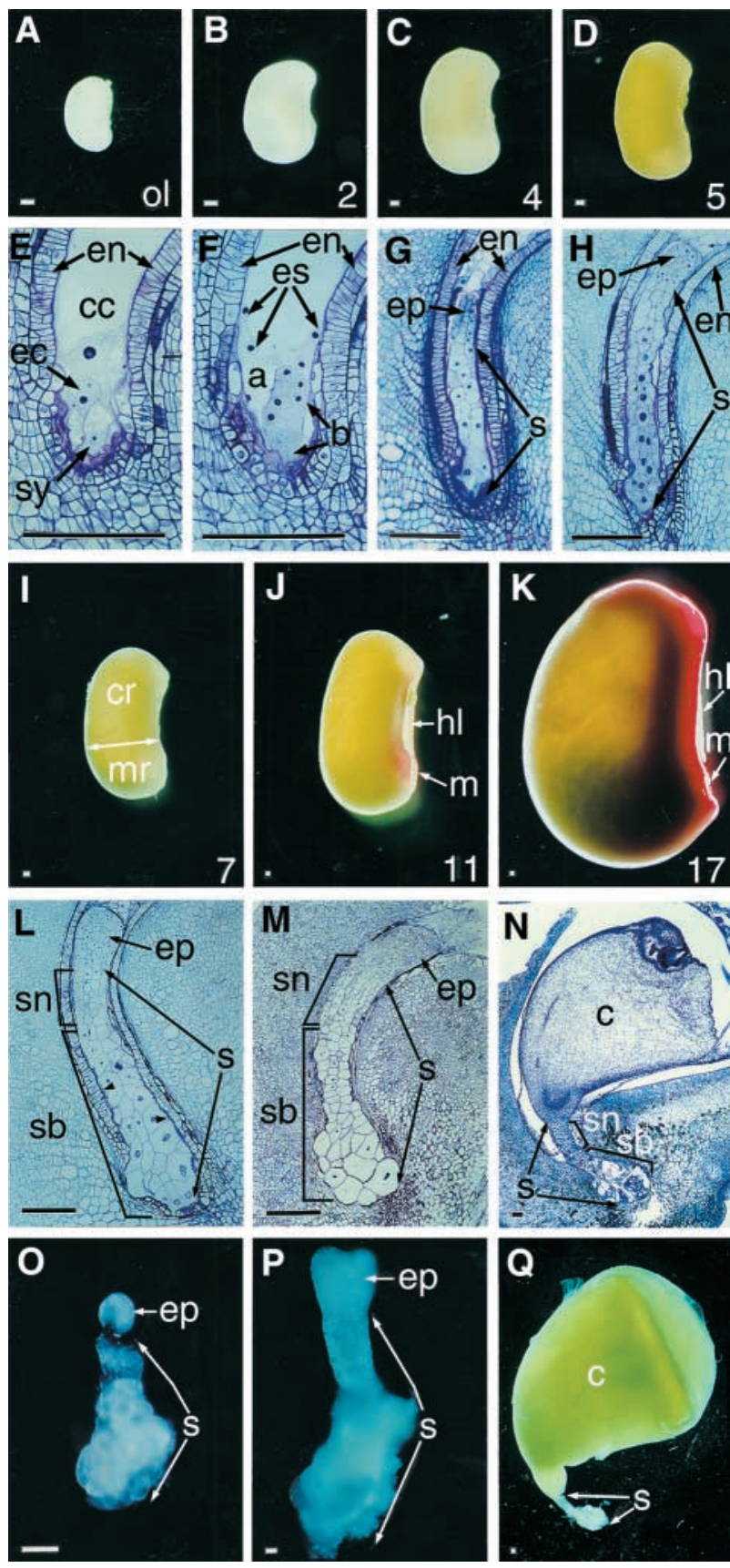

Figure 1. Scarlet Runner Bean Seed and Embryo Development.

(A) to (D) and (I) to (K) Seed development. The numbers indicate the stage of seed development in DAP. The seed micropylar region is oriented toward the bottom of the panel, as indicated in (I) to (K). The line with arrows across the 7-DAP seed (I) indicates where seed were microdissected into micropylar and chalazal regions for RNA isolation (see Methods).

$(\mathbf{E})$ to $(\mathbf{H})$ and $(\mathbf{L})$ to $(\mathbf{N})$ Embryo development. The development corresponds to the seed stage indicated in (A) to (D) and (I) to (K), respectively. (E) Embryo sac. (F) to (H) Proembryo stage. (L) and (M) synergids were bordered by the central cell (cc) at their chalazal ends (Figure 1E). At 2 DAP, the embryonic cells were organized irregularly, the apical (a) and basal (b) regions were morphologically indistinguishable, and endosperm (es) had started to form (Figure 1F). Just before the globular stage (4 DAP), the suspensor (s) of the filamentous embryo was distinguished from the embryo proper (ep) by its large, irregularly shaped cells (Figures $1 \mathrm{G}$ and $1 \mathrm{H}$ ) and was $\sim 200$ to $250 \mu \mathrm{m}$ in length (Figures $1 \mathrm{G}$ and $1 \mathrm{H}$, Table 1). By contrast, cells of the embryo proper were smaller and more uniform in size and shape (Figures $1 \mathrm{G}$ and $1 \mathrm{H}$ ).

Figures $1 \mathrm{~L}$ to $1 \mathrm{~N}$ show plastic sections of 7- to 17-DAP embryos. Whole-mount images of hand-dissected embryos (see Methods) at the same stages are shown in Figures 10 to $1 \mathrm{Q}$. The suspensor developed two distinct regions: a file of neck cells (sn) that connected suspensor to embryo proper and a set of large basal cells (sb) that protruded into the seed tissue (Figures $1 \mathrm{~L}$ to $1 \mathrm{Q}$ ). In the suspensor basal region, the number of cells remained constant and the increase in length of this region was attributable mainly to cell enlargement (Figures $1 \mathrm{~L}$ to $1 \mathrm{~N})$. The total suspensor length increased from 500 to 1000 $\mu \mathrm{m}$, which was its maximum size (Figures $1 \mathrm{~L}$ to $1 \mathrm{Q}$, Table 1 ). The embryo proper increased in cell size and number and developed from globular stage (Figures $1 \mathrm{~L}$ and 10 ) to heart stage (Figures $1 \mathrm{M}$ and $1 \mathrm{P}$ ) to cotyledon stage (Figures $1 \mathrm{~N}$ and $1 \mathrm{Q}$ ). At the cotyledon stage, the embryo proper was larger than the suspensor and contained chlorophyll, whereas the suspensor remained white (Figures $1 \mathrm{~N}$ and $1 \mathrm{Q}$ ). Together, these data show that the scarlet runner bean embryo differentiates a giant suspensor early in seed development (2 to $11 \mathrm{DAP}$ ) and that the time from pollination to seed maturity for Hammond's Dwarf Red Flower (Nagl, 1990; Voss et al., 1992) grown under our greenhouse conditions (see Methods) is similar to that of the original scarlet runner bean cultivar characterized by Walbot and colleagues nearly 30 years ago (Walbot et al., 1972b).

\section{Differential Display of Microdissected Suspensor RNA Yields Suspensor-Specific cDNA Clones}

We hand dissected suspensors from 6- to 7-DAP globularstage embryos (Figures $1 \mathrm{~L}$ and 10) and used differential

Globular stage. (N) Cotyledon stage. Arrows in (L) point to endothelium cell wall ingrowths contiguous to the suspensor.

(O) to (Q) Whole-mount photomicrographs of embryos at the globular stage (O), heart stage (P), and cotyledon stage (Q). These embryos were dissected from seeds at 7,11 , and 17 DAP, respectively ([I] to [K]).

a, apical region of proembryo; b, basal region of proembryo; c, cotyledon; cc, central cell; cr, chalazal region; ec, egg cell; en, endothelium; ep, embryo proper; es, endosperm; hl, hilum; m, micropyle; mr, micropylar region; o, unfertilized ovule; s, suspensor; sb, suspensor basal region; sn, suspensor neck region; sy, synergid. Bars $=100 \mu \mathrm{m}$. 
display-reverse transcription-polymerase chain reaction (DD-RT-PCR) to identify suspensor-specific mRNAs (see Methods). We selected cDNAs that were present in displays generated from (1) 6-DAP suspensor RNA (Figure 10) and (2) 6-DAP seed micropylar region RNA (Figure 1I) but that were absent in displays obtained from (1) 6-DAP seed chalazal region RNA (Figure 1I), (2) 6-DAP embryo proper RNA (Figure 10), and (3) leaf RNA as candidates for suspensorspecific sequences (data not shown; see Methods). Using these criteria, we obtained 25 potential suspensor-specific cDNAs that were $>0.2 \mathrm{~kb}$ in length, which were cloned and sequenced (see Methods).

\section{Population cDNA Gel Blot Analysis}

Because the amount of RNA we could obtain from microdissected suspensor and embryo proper regions was too small to verify the specificity of the cDNA clones by RNA gel blot analysis, we used DNA gel blots containing PCR-amplified population cDNAs (Kelly et al., 1990) to prescreen candidate cDNA clones (see Methods). We identified three DD-RTPCR cDNAs that hybridized with suspensor and seed micropylar region cDNAs but did not hybridize with seed chalazal region, ovule, or leaf cDNAs (data not shown; see Methods). These three clones were designated C541, G564, and G563 and represented putative suspensor-specific cDNAs. The other 23 cDNAs identified by DD-RT-PCR were not suspen-

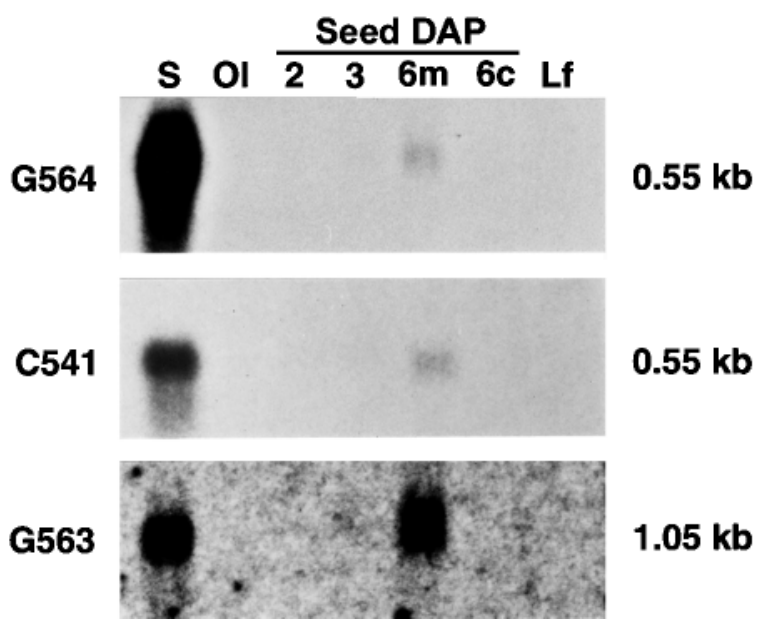

Figure 2. RNA Gel Blot Analysis of Putative Suspensor-Specific cDNA Clones.

Each lane contained $10 \mu \mathrm{g}$ of total RNA from suspensors of 6-DAP globular-stage embryos (S), unfertilized ovules (OI), whole seed at 2 DAP (2), whole seed at 3 DAP (3), 6-DAP seed micropylar regions $(6 \mathrm{~m}), 6-\mathrm{DAP}$ seed chalazal regions (6c), and leaves (Lf) (see Figure 1). The same RNA gel blot was used sequentially for all of the probes. Autoradiogram exposure times were 1 day for G564, 2 days for C541, and 7 days for G563. sor specific and represented false positives. Database searches with the putative suspensor-specific cDNAs indicated that they were not related to any protein of known function (see Methods). However, PSORT predicted that the G564 and C541 proteins might be either secreted (G564) or targeted to the vacuole (C541) (see Methods).

\section{RNA Gel Blot Analysis}

We hybridized G564, C541, and G563 cDNA probes to gel blots containing 6-DAP suspensor RNA (S), unfertilized ovule RNA (OI), 2-DAP seed RNA (2), 3-DAP seed RNA (3), 6 -DAP seed micropylar region RNA $(6 \mathrm{~m}), 6$-DAP seed chalazal region RNA (6c), and leaf RNA (Lf) to verify the results of total cDNA gel blot analysis. Figure 2 shows that the G564 and C541 probes did not hybridize detectably with unfertilized ovule, 2-DAP seed, 3-DAP seed, 6-DAP chalazal region, and leaf RNAs. By contrast, the G564 and C541 probes produced low signals with 6-DAP seed micropylar region RNA. These signals increased significantly with suspensor RNA isolated from 6-DAP micropylar region seed (Figure 2), suggesting that the lower G564 and C541 signals obtained with 6-DAP seed micropylar region RNA were caused by dilution of the suspensor RNA by nonembryonic seed tissue RNA (Figures $1 \mathrm{l}$ and 1L). The G564 suspensor hybridization signal was greater than that obtained with C541, indicating that G564 mRNA was present at a higher level than was C541 mRNA (Figure 2).

The G563 cDNA probe also did not hybridize detectably with unfertilized ovule, 2-DAP seed, 3-DAP seed, 6-DAP chalazal region, and leaf RNAs (Figure 2). In contrast to the G564 and C541 probes, however, the G563 probe produced equal hybridization signals with suspensor and 6-DAP micropylar RNAs, indicating that G563 hybridization intensity did not increase by enriching for suspensor RNA (Figure 2). In addition, the G563 hybridization signal with suspensor RNA was significantly lower than those obtained with the G564 and C541 cDNA probes (see Figure 2 legend). Together, these data show that G563, G564, and C541 mRNAs are prevalent within the micropylar region of 6-DAP seed and that G564 and C541 mRNAs are probably suspensor specific.

\section{G564 and C541 mRNAs Are Localized within the Suspensor}

We used in situ hybridization to visualize directly the seed and embryo regions that contained G564, C541, and G563 mRNAs. The results are shown in Figure 3.

\section{Localization of G564 and C541 mRNAs}

Figure 3A is a light microscopic image of a 7-DAP seed micropylar region longitudinal section showing the suspensor 

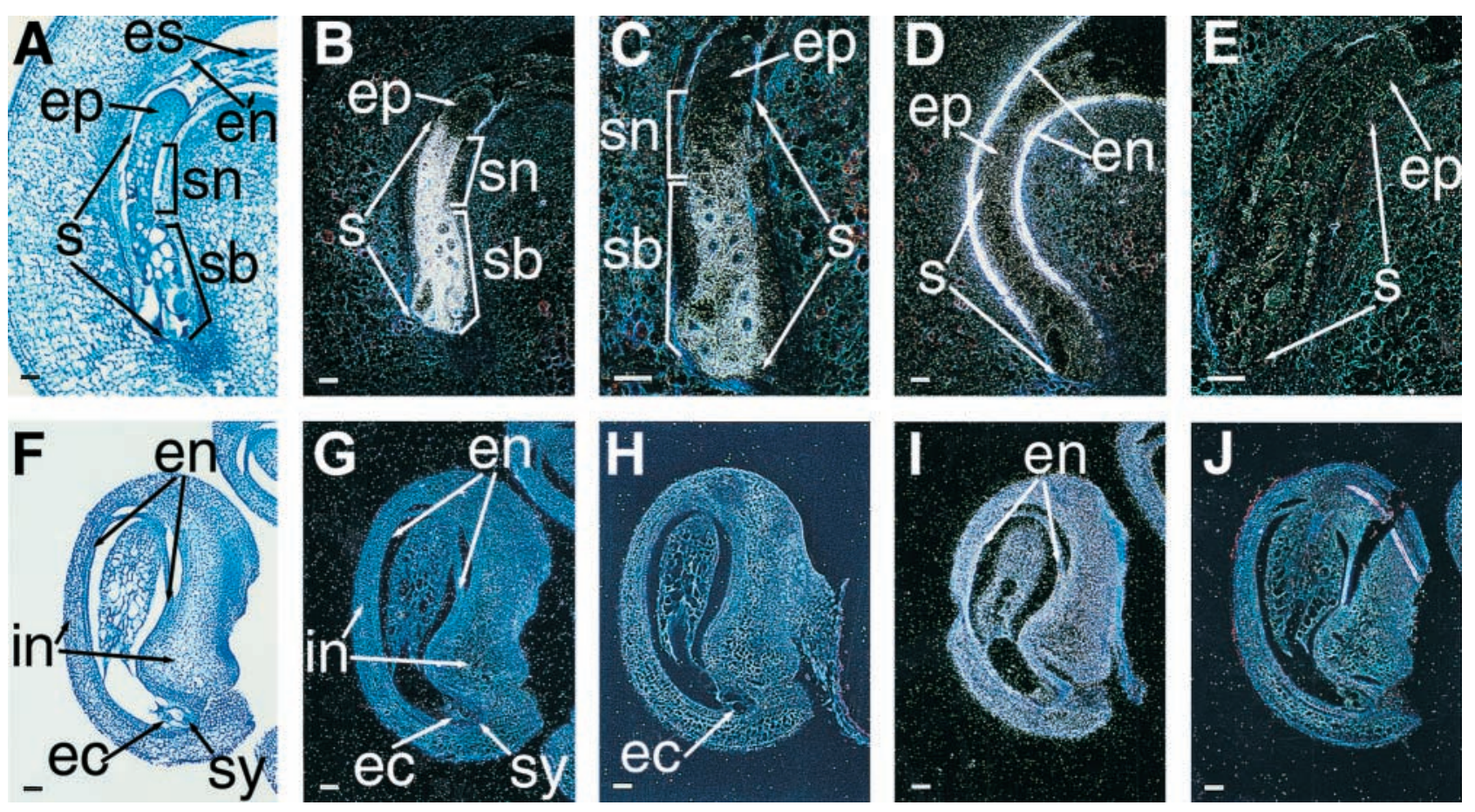

Figure 3. Localization of G564, C541, and G563 mRNAs in Unfertilized Ovules and 7-DAP Seed.

Ovules and seed were fixed, embedded in paraffin, sliced into $10-\mu \mathrm{m}$ sections, and hybridized with ${ }^{33}$ P-labeled sense or antisense probes as described in Methods.

(A) Bright-field photograph of a 7-DAP seed.

(B) to (D) Hybridization of 7-DAP seed with G564 (B), C541 (C), and G563 (D) anti-mRNA probes. Photographs were taken using dark-field microscopy. Slide emulsions were exposed for 19 days (B), 15 days (C), and 7 days (D).

(E) Hybridization of C541 sense control probe with 7-DAP embryo. The photograph was taken using dark-field microscopy. The slide emulsion was exposed for 11 days.

(F) Bright-field photograph of an unfertilized ovule.

(G) to (I) Hybridization of unfertilized ovules with G564 (G), C541 (H), and G563 (I) anti-mRNA probes. Photographs were taken using dark-field microscopy. Slide emulsions were exposed for 6 months (G), 9 months $(\mathbf{H})$, and 7 days (I), respectively.

(J) Hybridization of C541 sense background control probe with an unfertilized ovule. The photograph was taken using dark-field microscopy. The slide emulsion was exposed for 15 days.

ec, egg cell; en, endothelium; ep, embryo proper; es, endosperm; in, integument; s, suspensor; sb, suspensor basal region; sn, suspensor neck region; sy, synergid. Bars $=50 \mu \mathrm{m}$.

(s), suspensor neck region (sn), suspensor basal region (sb), embryo proper (ep), endosperm (es), and endothelium (en) that lines the cavity containing the developing embryo (Yeung and Clutter, 1978). Figures 3B and 3C show that the G564 and C541 mRNAs were localized specifically in the suspensor. No G564 or C541 hybridization signals were detected above background level (Figure 3E) in the embryo proper or in any nonembryonic tissue of the developing seed (Figures 3B and $3 \mathrm{C}$ ). A light microscopic image of a longitudinal section of an unfertilized ovule, showing the egg cell (ec), synergid (sy), integuments (in), and endothelium (en), is presented in Figure 3F. Figures 3G, 3H, and 4A show that no detectable G564 or C541 hybridization signals were observed above background (Figure $3 \mathrm{~J}$ and data not shown) in the embryo sac, including the egg cell and synergids (Fig- ure $4 \mathrm{~A})$, or in any ovule tissue, even after emulsion exposure times of 6 and 9 months, respectively.

\section{Localization of G563 mRNA}

Figure 3D shows that the G563 anti-mRNA probe hybridized specifically with transcripts in the seed endothelial layer (en) surrounding the embryo but not with those in the suspensor or the embryo proper. G563 mRNA was first detected within the endothelium at 3 DAP (data not shown). In contrast, no G563 hybridization signal above background level (Figures $3 \mathrm{E}$ and $3 \mathrm{~J}$ ) was visualized in the chalazal endothelium (Figure 3D and data not shown), the embryo sac, or in any unfertilized ovule tissue (Figures $3 \mathrm{~F}$ and $3 \mathrm{I}$ ). 

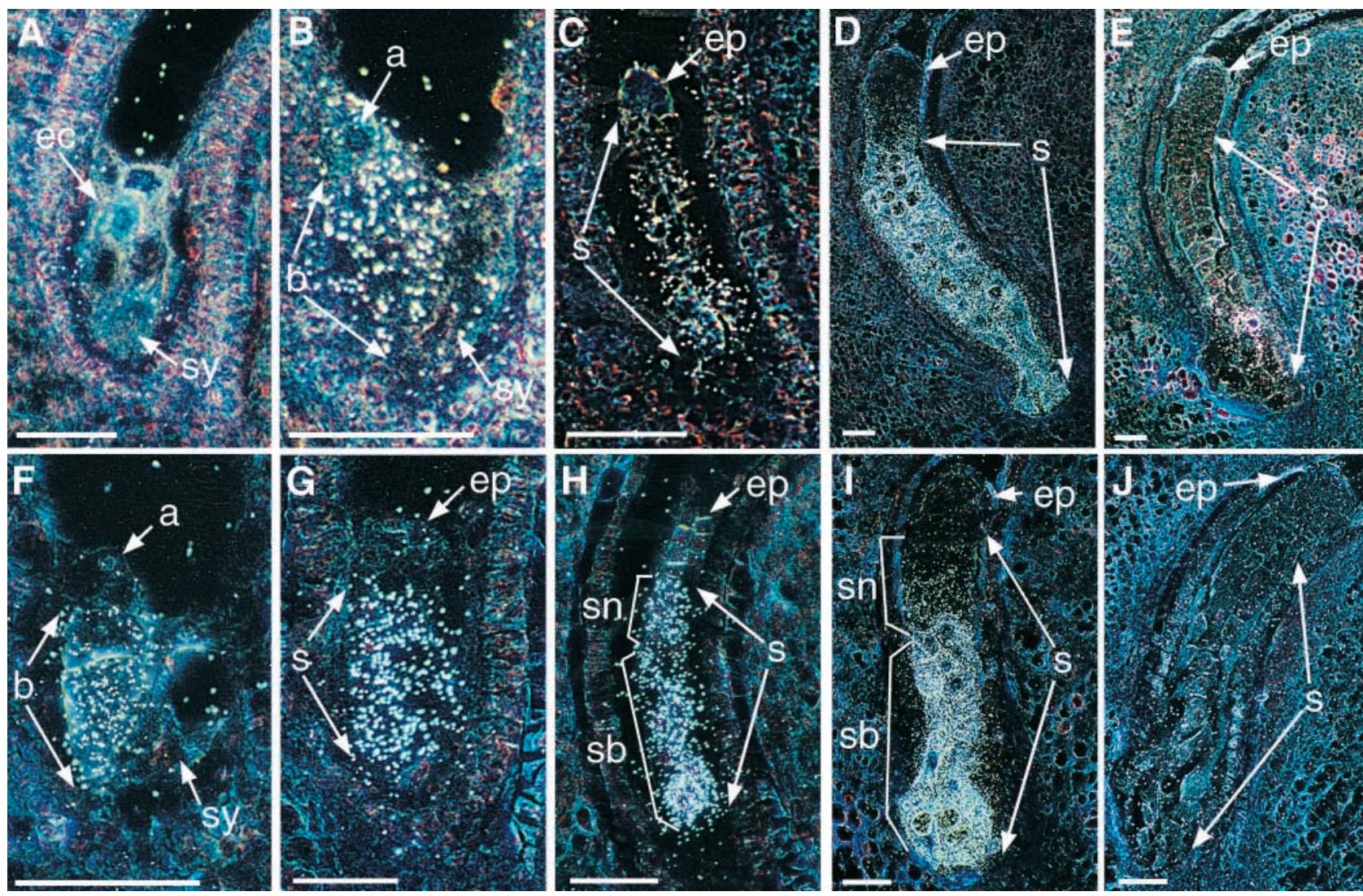

Figure 4. G564 and C541 mRNA Accumulation Patterns during Scarlet Runner Bean Embryo Development.

Tissues were fixed, embedded in paraffin, sliced into $10-\mu \mathrm{m}$ sections, and hybridized with ${ }^{33} \mathrm{P}$-labeled sense or antisense probes as described in Methods. Photographs taken using dark-field microscopy.

(A) to (D) Hybridization of G564 antisense probe with embryo sac and egg apparatus (A), 2-DAP embryo (B), 4-DAP embryo (C), and 7-DAP embryo (D). Slide emulsions were exposed for 6 months (A), 6 days (B), and 3 days (C) and (D).

(E) Hybridization of G564 sense probe with 7-DAP embryo. The slide emulsion was exposed for 7 days.

(F) to (I) Hybridization of C541 antisense probe with 2-DAP embryo (F), 3-DAP embryo (G), 4-DAP embryo (H), and 7-DAP embryo (I). Slide emulsions were exposed for 11 weeks (F) and 6 days (G) to (I).

(J) Hybridization of C541 sense probe with 7-DAP embryo. The slide emulsion was exposed for 11 days.

a, apical region of proembryo; b, basal region of proembryo; ec, egg cell; ep, embryo proper; s, suspensor; sb, suspensor basal region; sn, suspensor neck region; sy, synergid. Bars $=50 \mu \mathrm{m}$.

Together, these data show that the accumulation of C541, G564, and G563 mRNAs occurs after fertilization during seed development and that the G564 and C541 mRNAs are localized specifically within the suspensor region of globular-stage embryos.

\section{G564 and C541 mRNAs Accumulate Selectively within the Basal Region of the Four-Cell Proembryo}

We used in situ hybridization to investigate the accumulation pattern of G564 and C541 mRNAs during embryo development (Figure 1). As shown in Figures 4B (G564) and 4F
(C541), the G564 and C541 anti-mRNA probes detected transcripts exclusively in the two basal cells (b) of the fourcell proembryo before the suspensor and embryo proper regions could be differentiated (2 DAP). No G564 or C541 hybridization signals above background (Figures $4 \mathrm{E}$ and $4 \mathrm{~J}$ and data not shown) were detected in the two apical (a) cells of the same stage proembryo (Figures $4 \mathrm{~B}$ and $4 \mathrm{~F}$ ). Figure $4 G$ shows that the C541 mRNA remained localized asymmetrically within proembryo basal cells at 3 DAP, like the G564 mRNA (data not shown).

As shown in Figures 4C and 4D (G564) and Figures $4 \mathrm{H}$ and $4 \mathrm{I}$ (C541), G564 and C541 mRNAs were detectable exclusively in the suspensor (s) from the early globular stage (4 
DAP) to the globular stage (7 DAP). No G564 or C541 hybridization signals above background (Figures 4E and 4J) were detected within the embryo proper. G564 mRNA was distributed evenly over the entire suspensor (Figures $4 \mathrm{C}$ and 4D). By contrast, C541 mRNA sequences were more concentrated in the large cells of the suspensor basal region compared with those in the suspensor neck region (Figures $4 \mathrm{H}$ and $4 \mathrm{l})$.

We hybridized the G564 anti-mRNA probe with 23-DAP embryo sections to determine whether G564 mRNA was present at later stages of embryogenesis. The inset in Figure 5 is a whole-mount image of a 23-DAP embryo showing one cotyledon (c) and the axis and plumule (boxed). Figure 5 shows that G564 mRNA was not detected in the cotyledon. In contrast, G564 transcripts were present in the axis but were concentrated primarily within the meristematic zone at the axis tip (Figure 5).

Together, these results show that G564 and C541 suspensor mRNAs are first detectable two divisions after fertilization and are localized asymmetrically within the basal cells of the proembryo before suspensor differentiation and that, later in development, G564 mRNA accumulates within the embryonic axis.

\section{G564 mRNA Accumulation within the Proembryo Basal Region Is Transcriptionally Controlled}

We isolated the G564 gene from a scarlet runner bean genomic library to determine whether the basal region-specific and suspensor-specific G564 mRNA accumulation patterns were regulated at the transcriptional or post-transcriptional level. Figure 6A shows a scheme of a 6.99-kb genomic fragment from the scarlet runner bean containing the G564 gene. We found that the G564 coding region was $659 \mathrm{bp}$ long, consisted of two exons of 107 and $388 \mathrm{bp}$, and contained one 164-bp intron. The $5^{\prime}$ and $3^{\prime}$ regions included in the genomic fragment were 4242 and 2085 bp in length, respectively. In the $5^{\prime}$ region, we identified a putative gene at positions -4214 to -2588 with similarity to the Arabidopsis Pol3 gene (GenBank accession number AC005561).

\section{Localization of G564 mRNA in Transgenic Tobacco Embryos Containing the G564 Gene}

We introduced the 6.99-kb G564 genomic clone (Figure 6A) into tobacco plants and localized G564 mRNA during embryo development. Figure $6 \mathrm{~B}$ shows that, like the scarlet runner bean embryo (Figure 4B), G564 mRNA was localized specifically in the basal region of the preglobular-stage embryo and was not detectable in the apical region. At this stage of tobacco embryo development, the basal region had developed into an immature suspensor (s) that was distinguishable from the embryo proper (ep) (Figure 6J and data not shown). Figure $6 \mathrm{C}$ shows that at the globular stage,
G564 mRNA was highly concentrated in the suspensor and in the hypophyseal and basal regions (h) of the embryo proper. Figures 6D and 6E show that in heart- and torpedostage embryos, G564 transcripts were localized primarily in the basal tip of the axis (ax), like that observed in scarlet runner bean early maturation-stage embryos (Figure 5). In addition, Figures 6D and 6E show that G564 mRNA accumulated in the endosperm (es) that persists late in tobacco seed development. No hybridization signal above background level was detected in nontransformed tobacco embryos (data not shown). Together, these results indicate that all of the control elements necessary for the localization of G564 mRNA within the basal region and suspensor early in embryo development are contained within the 6.99-kb G564 genomic clone and that these elements are recognized by the relevant regulatory proteins in widely divergent plants.

\section{G564/GUS Gene Expression in Transgenic Tobacco Embryos}

We introduced a chimeric G564/GUS gene into tobacco and localized GUS mRNA and GUS enzyme activity in transgenic embryos to study G564 transcriptional regulation. The G564/GUS gene contained $4.2 \mathrm{~kb}$ of $5^{\prime}$ flanking sequence (Figure 6A; see Methods). Figure $6 \mathrm{~J}$ shows that there was a high level of GUS enzyme activity in the two suspensor cells

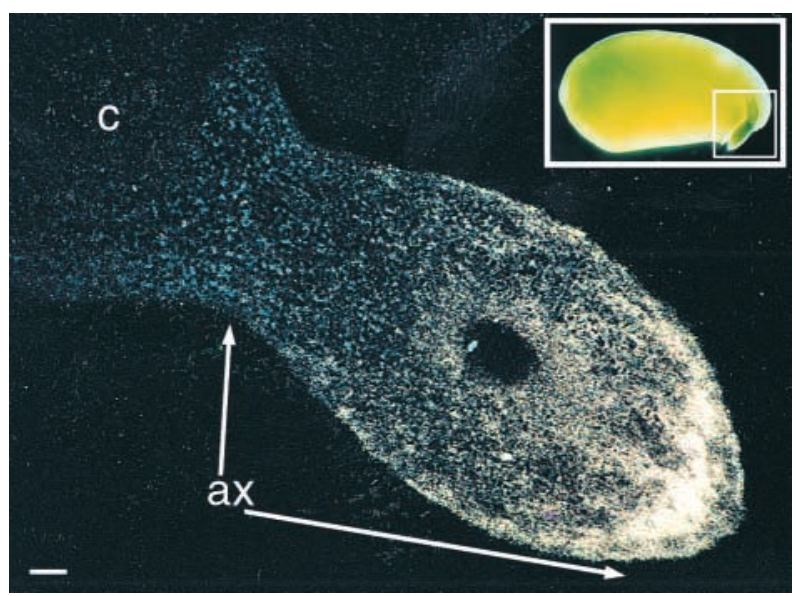

Figure 5. G564 mRNA Localization Pattern within the Axis of an Early Maturation-Stage Embryo.

Axis regions of 23-DAP seed were fixed, embedded in paraffin, sliced into $10-\mu \mathrm{m}$ sections, and hybridized with a ${ }^{33} \mathrm{P}-$ labeled G564 antisense probe as described in Methods. The photograph was taken using dark-field microscopy. The slide emulsion was exposed for 4 days. The inset shows a whole-mount bright-field image of an early maturation-stage embryo at $23 \mathrm{DAP}$. The embryo region used for localization of the G564 mRNA within the axis is boxed. ax, axis; c, cotyledon. Bar $=100 \mu \mathrm{m}$. 
A


Figure 6. Analysis of Transgenic Tobacco Embryos Containing Either a G564 or a G564/GUS Gene.

(A) Scheme of the G564 gene. Blue blocks delineate the exons, including the amino acid coding sequence, ATG, exon-intron junctions, and stop codon. The yellow block represents an intron. Numbers indicate the last and/or first nucleotides of each exon. The last downstream nucleotide of the genomic clone also is indicated. Numbering is relative to the first upstream nucleotide identified in the G564 cDNA sequence. Po/3, a gene sharing homology with POL3 in Arabidopsis. 
of the five-cell preglobular embryo. In contrast, no GUS activity was detected in the embryo proper (Figure 6J). Figure 6F shows that GUS mRNA was not detected above background level in the same-stage embryos, indicating that in the suspensor, GUS mRNA was below the detection level of the in situ hybridization procedure. At the globular stage, both GUS activity and GUS mRNA were detectable in the suspensor and in the hypophyseal and basal regions of the embryo proper, as shown in Figures $6 \mathrm{G}$ and $6 \mathrm{~K}$, respectively. Later in development, at the heart and torpedo stages, both GUS mRNA and enzyme activity were detectable in the axis, as shown in Figures $6 \mathrm{H}$ and $6 \mathrm{I}$ and Figures $6 \mathrm{~L}$ and $6 \mathrm{M}$, respectively. GUS transcripts also were detected in the endosperm at these stages of seed development (Figures $6 \mathrm{H}$ and $6 \mathrm{I}$ ). Together, these data indicate that (1) the G564 promoter is activated specifically in the basal cells soon after fertilization, and (2) G564 mRNA accumulates asymmetrically within the basal cells and suspensor during early embryo development (Figures 3 to 5) primarily as a result of transcriptional control processes.

\section{5' Deletion Analysis of the G564 Promoter Identifies a Region Required for Suspensor-Specific G564/GUS Expression}

We generated $5^{\prime}$ nested deletions of the G564 promoter fused to the GUS reporter gene (see Methods) and introduced these deletions into tobacco plants to identify suspensor-specific G564 cis-regulatory regions. Figure 7A shows that progressively deleting the G564 promoter from -4242 to -921 did not affect the suspensor-specific pattern of GUS enzyme activity in early globular-stage embryos (eight to 32 cells). Nor was GUS enzyme activity affected in the embryo proper basal region and axis later in embryo development (Figures $6 \mathrm{G}$ to $6 \mathrm{M}$ and data not shown). Deleting the region between -921 and -662 , however, abolished suspensorspecific GUS activity (Figure 7A). Upon further deletion of the G564 promoter (to the transcription start site), GUS activity did not reappear in the suspensor (data not shown).
Nucleotide sequence analysis of the region from -921 to -662 revealed an 80-bp conserved sequence that is repeated four times within the G564 promoter at positions -1327 to $-1247,-1183$ to $-1105,-1030$ to -950 , and -885 to -805 , as shown in Figure $7 \mathrm{~B}$. Preliminary gainof-function analysis showed that a -1368 to -1208 G564 promoter fragment containing one of these 80 -bp repeats is sufficient to drive suspensor-specific GUS expression from a minimal Cauliflower mosaic virus $35 \mathrm{~S}$ promoter (K. Weterings, Y.-P. Bi, and R.B. Goldberg, unpublished data). Moreover, within these repeats, we identified a 10-bp sequence, $5^{\prime} \mathrm{GAAAAGC} / \mathrm{TGAA3}$ ' (Figure 7B), that also is present in the C541 promoter but is absent from (1) the Kti1 and Kti2 Kunitz trypsin inhibitor promoters (accession number S45035; Jofuku and Goldberg, 1989), (2) the Kti3 Kunitz trypsin inhibitor promoter (accession number S45092; Jofuku et al., 1989), and (3) the Le1 Lectin promoter (GenBank accession number K00821; Vodkin et al., 1983) that are active only in the embryo proper region of transgenic tobacco embryos (De Paiva, 1994; Goldberg et al., 1994; Yadegari, 1996). Together, these data suggest that there are one or more positive suspensor-specific cis-regulatory elements present in the G564 promoter between nucleotides -921 and -662 .

\section{DISCUSSION}

We used the scarlet runner bean embryo as a model system to investigate gene expression programs during early embryogenesis. We identified two suspensor-specific mRNAs designated G564 and C541. In four-cell embryos, G564 and C541 mRNAs accumulate exclusively in the two basal cells but are not detectable in the two apical cells. A chimeric G564/GUS reporter gene is transcribed specifically in the basal cells of transgenic tobacco embryos at a similar stage (five-cell stage). We conclude from these results that as early as the four-cell embryo stage, the apical and basal cells transcribe different gene sets and are specified at the molecular level.

Figure 6. (continued).

(B) to (I) Accumulation patterns of G564 mRNA ([B] to [E]) and GUS mRNA ([F] to [I]) in transgenic tobacco embryos carrying the scarlet runner bean G564 gene (A) or the G564/GUS gene (see Figure 7A), respectively. Tissues were fixed, embedded in paraffin, sliced into 10- $\mu \mathrm{m}$ sections, and hybridized with ${ }^{33}$ P-labeled antisense G564 probe ([B] to [E]) or GUS antisense probe ([F] to [I]) as described in Methods. Photographs were taken using dark-field microscopy. (B) and (F) Preglobular-stage embryo. (C) and (G) Globular-stage embryo. (D) and (H) Heart-stage embryo. (E) and (I) Torpedo-stage embryo. Slide emulsions were exposed for 39 days ([B] and [F]), 16 days ([G] to [I]), or 8 days ([C] to [E]).

(J) to (M) GUS enzyme activity in transgenic tobacco embryos carrying the G564/GUS chimeric gene. Embryos were dissected from tobacco seed at different stages of development and incubated in GUS assay buffer as described in Methods. (J) Preglobular stage. (K) Globular stage. (L) Heart stage. (M) Torpedo stage. For (J) and (K), photographs were taken using bright-field microscopy. For (L) and (M), photographs were taken using dark-field microscopy. GUS assay incubation time was $16 \mathrm{hr}$ (J) or $1 \mathrm{hr}$ ([K] to [M]).

ax, axis; c, cotyledon; ep, embryo proper; es, endosperm; h, hypophyseal region; s, suspensor. Bars $=50 \mu \mathrm{m}$. 
A

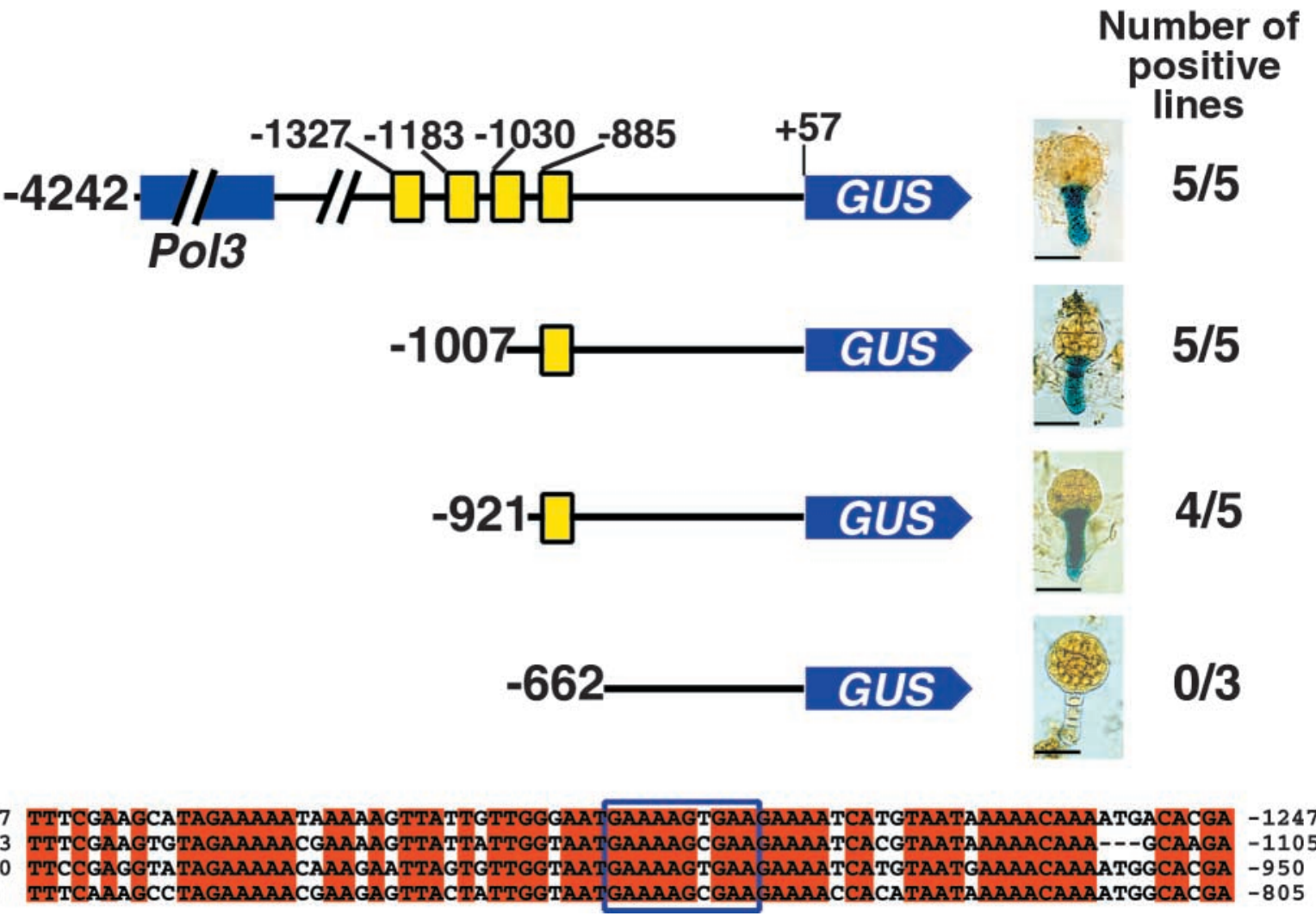

Figure 7. 5' Deletion Analysis of the G564 Promoter and Alignment of an 80-bp Conserved Repeat.

(A) Suspensor-specific GUS enzyme activity in early globular-stage (eight- to 32-cell stage) transgenic tobacco embryos containing different $5^{\prime}$ truncated G564 promoter-GUS constructs. The scheme to the left of each embryo depicts the 5' truncated G564 promoter-GUS construct carried by the transgenic embryo. The number to the left of each scheme indicates the deletion position. Blue blocks delineate the coding regions for the Po/3 and GUS genes, respectively. Yellow blocks indicate the 80-bp conserved repeats and their starting positions. The numbers to the right of each embryo indicate the number of individual transformants displaying early globular-stage, suspensor-specific GUS enzyme activity per total number of transformed individuals analyzed. GUS assay incubation times were $16 \mathrm{hr}$ for embryos carrying constructs $-4242,-1007$, and -921 and $40 \mathrm{hr}$ for embryos carrying construct -662 . Bars $=50 \mu \mathrm{m}$.

(B) Nucleotide sequence alignment of the four 80-bp conserved repeats in the G564 promoter as indicated by yellow blocks in the G564 promoter-GUS schemes shown in (A). The nucleotides conserved across all four repeat sequences are highlighted in red. The 10-bp sequence $(\mathrm{GAAAAGC} / \mathrm{T} \mathrm{GAA})$ that also is present in the $\mathrm{C} 541$ promoter is boxed. In the sequence from -1183 to -1105 , a three-nucleotide gap was introduced for optimal alignment.

\section{Scarlet Runner Bean Suspensor Provides a Unique Opportunity to Study the Earliest Events in Plant Embryogenesis}

Scarlet runner bean has been used historically as a model system to study embryo development (Walbot et al., 1972b; Sussex et al., 1973; Nagl, 1974; Yeung and Clutter, 1978; Yeung and Sussex, 1979; Yeung and Meinke, 1993). The scarlet runner bean embryo is relatively large-five to six times larger than Arabidopsis embryos, for example (Figure 1; Mansfield and Briarty, 1991)-and it can be isolated easily at the globular stage (Figure 10). In this article, we show that we can microdissect suspensors from scarlet run- ner bean globular-stage embryos (Figure 10) and use genomics techniques to identify suspensor-specific gene transcripts (Figures 2 to 4). Recently, we also have been able to use mRNAs from scarlet runner bean embryo proper and suspensor regions (Figure 10) to generate cDNA libraries and study the transcript profiles of different regions of the same globular-stage embryo by expressed sequence tag analysis (A.Q. Bui, K. Weterings, and R.B. Goldberg, unpublished data; http://www.mcdb.ucla.edu/Research/ Goldberg/EST/). In addition, we have been able to identify Arabidopsis genes corresponding to G564, C541, and other scarlet runner bean genes that are active early in embryo development, and we are applying reverse genetics (Winkler 
et al., 1998) to help identify what role, if any, these genes play in suspensor and/or embryo development (A.Q. Bui, B. Le, K. Weterings, and R.B. Goldberg, unpublished data). Thus, the giant scarlet runner bean embryo provides a unique model system to investigate the earliest events of plant embryogenesis, either directly using genomics approaches or indirectly as a starting point for genetic analysis in Arabidopsis.

\section{A Mosaic of Gene Expression Programs Is Active during Early Seed Development}

In flowering plants, fusion of the sperm cells with both the egg cell and the central cell initiates embryo and endosperm development, respectively (Figure 1, Table 1). In addition, fertilization causes the integument and the endothelium to differentiate and to contribute to the development of the seed (Figure 1, Table 1) (Johri, 1984; Raghavan, 1986; Miller et al., 1999). Simultaneously, a cascade of different gene expression programs is initiated that is correlated with the various events that occur during embryo and seed development (Goldberg et al., 1989, 1994). For example, in this article, we show that G563 mRNA begins to accumulate specifically at 3 DAP in the seed micropylar endothelium surrounding the developing embryo (Figure 3D and data not shown). The micropylar endothelium cell layer has been proposed to function as an embryo-nursing tissue by exchanging metabolites with the suspensor via extensive cell wall ingrowths that appear at 3 DAP (Figure 1L) (Yeung and Clutter, 1978, 1979; Natesh and Rau, 1984). Because of this tight contact between endothelium and suspensor, some residual endothelial cells probably were present in our handdissected suspensor preparations, explaining why we identified G563 as a micropylar endothelium-specific transcript (Figures 2 and 3D). The correlation between G563 mRNA and the appearance of cell wall ingrowths contiguous to the suspensor of the developing embryo suggest that G563 marks the specification of the micropylar endothelium as an embryo-nursing tissue. Although the function of the predicted G563 protein is unknown, its high glycine and proline contents ( 47.5 and $12.5 \%$, respectively) suggest a structural role (Showalter, 1993), perhaps in the formation of the specialized cell wall ingrowths.

By contrast, G564 and C541 mRNAs accumulate specifically in the suspensor. G564 transcripts are distributed evenly over the whole suspensor (Figures $3 B$ and 4D), whereas C541 transcripts accumulate to a higher concentration in the suspensor basal region than in the suspensor neck region (Figures $3 \mathrm{C}, 4 \mathrm{H}$, and $4 \mathrm{l}$ and data not shown). Recently, other suspensor mRNAs have been identified. One, ZmOCL3, accumulates in maize suspensors and encodes a homeobox transcription factor (Ingram et al., 2000). The other encodes an Arabidopsis ASK $\eta$ protein kinase (Dornelas et al., 1999). On the basis of physiological and cytological studies, the main activities of the suspensor are importing, producing, and transporting nutrients and growth regulators to the developing embryo proper (Schnepf and Nagl, 1970; Brady, 1973; Sussex et al., 1973; Clutter et al., 1974; Alpi et al., 1979; Yeung and Clutter, 1979; Ceccarelli et al., 1981; Yeung and Meinke, 1993). The exact functions of G564 and C541 proteins in suspensor activities are unknown. However, the fact that C541 is predicted to be targeted to the vacuole might explain the higher concentration of C541 mRNA in the highly vacuolate suspensor basal region.

Together, the G563, G564, and C541 mRNA accumulation patterns demonstrate that different gene regulatory programs are required for both the differentiation and function of unique seed and embryo regions. How these programs are initiated and coordinated during seed development remains to be established.

\section{Differentiation of Early Embryo Apical and Basal Regions Is Marked by the Accumulation of Different mRNAs}

The suspensor is derived from the basal cell of the two-cell embryo. It is not known what mechanisms direct the basal cell to become specified and develop into a suspensor. Nor is it known when these mechanisms become active. To elucidate the gene circuits that regulate suspensor development and, thus, the regulatory networks that control apicalbasal cell specification events, we investigated G564 and C541 mRNA localization patterns before and after fertilization (Figures 3B and 3C). We found that the G564 and C541 transcripts are not detectable within the ovule and that these mRNAs first appear in the two basal cells of the fourcell embryo before the suspensor is morphologically distinguishable (Figures 4B and 4F). No detectable G564 or C541 mRNAs are present in the apical cell, indicating that these mRNAs are localized asymmetrically within the embryo two divisions after fertilization. These results suggest that both the G564 and C541 genes are activated after fertilization and that the G564 and C541 mRNAs accumulate specifically in basal cells destined to become the suspensor. By contrast, transcripts of the Arabidopsis homeobox gene ATML1 (Lu et al., 1996) and the Arabidopsis PHABULOSA gene (McConnell et al., 2001) accumulate exclusively in the apical cell and the 16-cell embryo proper region, respectively. Together, these data show that at the four-cell embryo stage, the apical and basal regions have been specified from each other and that this specification is marked by the accumulation of different mRNAs. These results suggest that mechanisms specifying the embryo apical and basal regions are active immediately after fertilization.

\section{Basal Region-Specific mRNA Accumulation Is Caused by Specific Transcriptional Programs}

We began to unravel the basal region-specifying mechanisms by studying the regulation of G564 mRNA accumulation in 


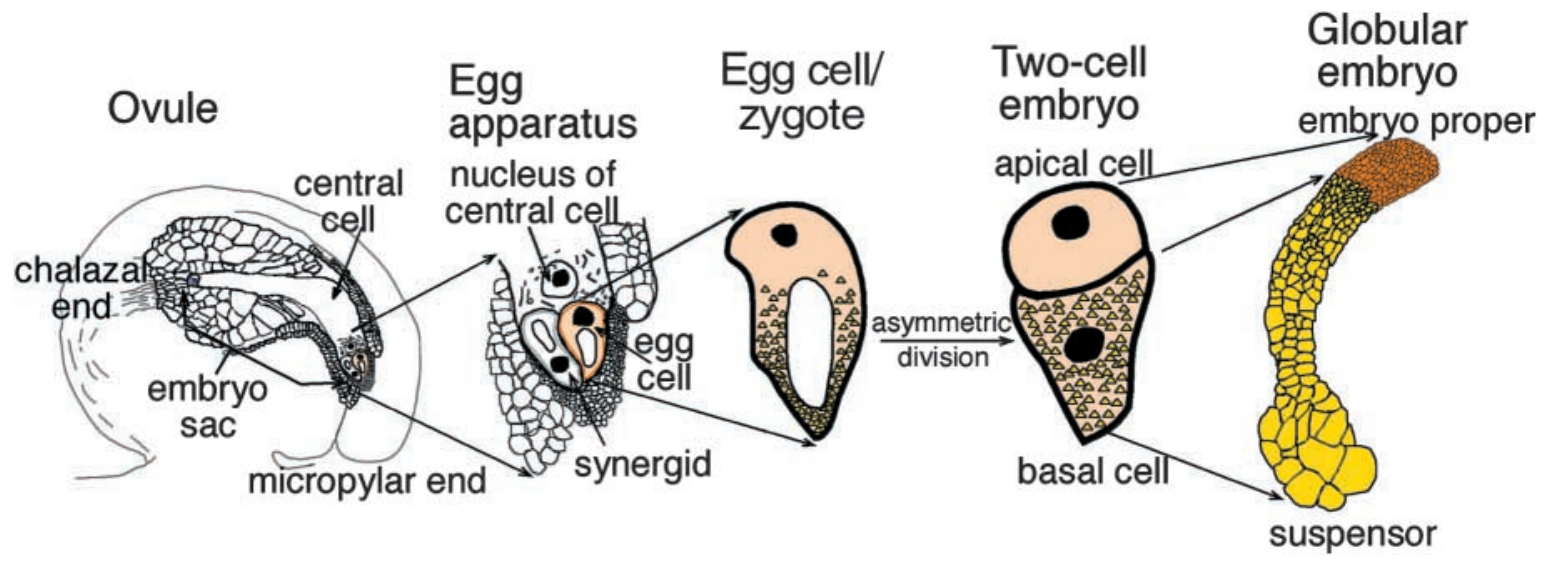

Figure 8. Mechanism of Basal Cell and Suspensor Specification.

Basal cell-specifying morphogenetic factors (yellow triangles) are distributed asymmetrically in the cytoplasm of the egg cell or zygote. Upon asymmetric division, these factors are inherited by the basal cell and trigger the transcription of basal region-specific genes such as G564 and, eventually, the specification of the suspensor.

transgenic tobacco embryos carrying the scarlet runner bean G564 gene. We found that the G564 mRNA accumulation pattern in transgenic tobacco embryos is similar to that observed during scarlet runner bean embryo development (Figures 4B, 5, 6B, and 6C). This finding shows that the 6.99-kb G564 genomic clone is a marker for the specification of the four-cell embryo basal region and that within this 6.99-kb genomic fragment are sequences required for the asymmetric accumulation of G564 mRNA during early embryogenesis. This observation also shows that despite differences between tobacco and scarlet runner bean embryos with respect to early embryo cell division patterns and suspensor size and shape (Figures $1 \mathrm{E}$ to $1 \mathrm{H}, 1 \mathrm{~L}, 1 \mathrm{M}$, and $6 \mathrm{~B}$ to 6M) (Natesh and Rau, 1984; Kaplan and Cooke, 1997), the underlying basal cell- and suspensor-specific gene regulatory mechanisms are conserved between these distantly related plant species (Goldberg et al., 1994), suggesting that events leading to basal cell specification and suspensor differentiation are ancient and have been conserved in flowering plants.

We found that GUS enzyme activity is localized in basal region- and suspensor-specific patterns in transgenic tobacco embryos containing the chimeric G564/GUS gene. These patterns are similar to the G564 mRNA accumulation patterns in scarlet runner bean embryos and G564 transgenic tobacco embryos (Figures 4B, 6B, 6C, 6J, and 6K), indicating that the mechanism that regulates basal regionand suspensor-specific G564 mRNA accumulation operates primarily at the transcriptional level. This result implies that the differentiation of the basal and apical regions requires the activation of apical region- and basal region-specific transcription programs that are conserved between these distantly related plant species.
Our data indicate that a region between -921 and -662 within the G564 promoter contains sequences that interact with the basal region-specific transcription process (Figure 7). Recently, our scarlet runner bean expressed sequence tag project (http://www.mcdb.ucla.edu/Research/Goldberg/ EST/) identified several transcription factor mRNAs present in the suspensor of globular-stage embryos. One mRNA encoding a homeobox protein has an accumulation pattern similar to that shown in Figures 3 and 4 for the G564 and C541 mRNAs (Y.-P. Bi, A.Q. Bui, and R.B. Goldberg, unpublished data). What role these transcription factors play in suspensor differentiation and/or activation of the G564 gene remains to be determined.

\section{A Model for the Specification of the Apical and Basal Cells of the Two-Cell Embryo}

How is the G564 transcriptional program activated specifically in the embryo basal region, and how does this provide clues about the general mechanisms that specify basal cell fate? A possible explanation might involve the apical-basal polarized cytoarchitecture of the egg cell and zygote (Figure $1 \mathrm{E} ;$ Willemse and van Went, 1984). The asymmetric distribution of cytoplasm and/or its contents within the egg and/or zygote may play a role in activating specific apical and basal region transcription programs (Goldberg et al., 1994). Figure 8 illustrates a heuristic model for the specification of basal cells leading to suspensor differentiation. This model assumes that there is an asymmetric distribution of "morphogenetic factors" (e.g., transcription factors) within either the egg cell or the zygote, or both. In addition, it assumes that the basal cell (and suspensor) is specified autonomously as a 
consequence of inheriting the morphogenetic factors after zygotic division. These factors trigger a cascade of events leading to the transcription of basal region-specific genes, such as G564, and suspensor differentiation (Figure 8).

The model shown in Figure 8 is consistent with analogous autonomous specification processes that occur for specific cell types during embryo development in various animal systems (Davidson et al., 1998). In plants, this model predicts that the embryo basal region-specific transcription of the G564 gene (Figures 4B, 6B, and 6J) is programmed by one or more basal cell-specific transcription factors and that these transcription factors are derived initially from the basal region of the egg cell or zygote. It is possible that these regulatory factors are bound by the cytoskeleton to the basal pole of the egg and/or the zygote and that these factors automatically become part of the basal cell after zygote division. This would be similar to the mechanism responsible for targeting factors to unique intracellular cytoplasmic locations in animal embryos (Yisreali et al., 1990; Lall et al., 1999) and to the process by which the polarized axis is fixed in Fucus eggs (Kropf, 1997; Quatrano, 1997).

Alternatively, it is possible that a signaling mechanism similar to that which establishes dorsal/ventral polarity in Drosophila embryos (Davidson et al., 1998; Sen et al., 1998) is responsible for basal cell specification. In this case, a signal derived from the maternal seed tissues contiguous with the basal cell (e.g., endothelium) would interact with a basal cell ligand, which then would trigger a signal transduction cascade leading to transcription of basal region-specific genes such as G564 and, subsequently, to suspensor differentiation. One prediction of this model is that the factors that activate G564 transcription should be present in both the apical and basal cells of the embryo but remain inactive within the apical cell (Davidson et al., 1998).

The giant scarlet runner bean embryo (Figure 1) and the availability of basal cell-specific markers, such as G564 and C541, should allow us to test predictions of the model presented in Figure 8 and obtain new insights into how the apical and basal cells of a plant embryo are specified to follow different developmental fates.

\section{METHODS}

\section{Plant Materials and Growth Conditions}

Seeds of the day-neutral scarlet runner bean (Phaseolus coccineus) cultivar Hammond's Dwarf Red Flower were purchased from the Vermont Bean Seed Company (Fair Haven, VT) (Nagl, 1990; Voss et al., 1992). Scarlet runner bean seeds were germinated in a soil mixture of vermiculite, perlite, sandy loam soil, sphagnum peat moss, and plaster sand at a ratio of 3:3:2:2:2. Plants were maintained in a 16-hr-light/ 8-hr-dark cycle in the greenhouse. Flowers were hand pollinated by lightly brushing the stigma with a watercolor brush containing pollen. Hand-pollinated flowers were tagged, and seeds were harvested at specific days after pollination (DAP).

\section{Suspensor Isolation}

The micropylar half of a 6- to 7-DAP seed (Figures $1 \mathrm{~L}$ and 10) was cut and placed upright on its cut side on the stage of a dissecting microscope. Approximately $1 \mathrm{~mm}$ was sliced from the left and right sides of the seed coat "flat face." The seed was turned on its flat face, and the remaining seed coat and endosperm were removed from the exposed embryo proper. The entire embryo was isolated, and the suspensor was separated from the embryo proper by microdissection. We were able to dissect globular embryos (Figure 10) at the rate of $\sim 10$ per $\mathrm{hr}$ and collect separately the embryo proper and suspensor regions.

\section{RNA Isolation and Gel Blot Analysis}

Polysomal RNAs were isolated according to the procedure of Cox and Goldberg (1988). Poly(A) mRNA was isolated from total polysomal RNA using the PolyATract mRNA isolation system (Promega, Madison, $\mathrm{WI}$ ) and the protocol supplied by the manufacturer. Total RNAs, used for differential display-reverse transcription-polymerase chain reaction (DD-RT-PCR) and RNA gel blot experiments, were isolated using the RNAeasy plant total RNA kit (Qiagen, Chatsworth, CA). We determined that we could isolate $20 \mu \mathrm{g}$ of total RNA from 250 suspensors and $300 \mathrm{ng}$ of total RNA from 200 embryo proper regions.

RNAs were treated with RNase-free DNase (Boehringer Mannheim, Indianapolis, IN) according to the protocol of Ausubel et al. (1992). RNA gel blot analysis was performed as described by Sambrook et al. (1989). ${ }^{32}$ P-labeled DNA probes for the RNA gel blots were prepared by the random priming procedure of Feinberg and Vogelstein (1984).

\section{cDNA Library Construction}

A cDNA library of 5- to 9-DAP scarlet runner bean seeds containing globular-stage embryos (Figures 1D and 11) was constructed using the ZAP Express cDNA synthesis kit (Stratagene, La Jolla, CA). Poly(A) mRNA was used as a template to generate first-strand cDNA using Moloney murine leukemia virus (MMLV) reverse transcriptase and a 50base oligonucleotide linker primer (5'-[GA] $]_{10}$ ACTAGTCTCGAGT $\left.]_{18}-3^{\prime}\right)$. Double-stranded cDNAs were blunt ended and ligated to an EcoRI adapter. After phosphorylation of EcoRI $5^{\prime}$ ends, the cDNAs were digested with Xhol and size fractionated on a Sephacryl S-400 column to exclude cDNAs that were smaller than $250 \mathrm{bp}$. The fractionated cDNAs were ligated to the $\lambda Z A P$ vector.

\section{DD-RT-PCR}

DD-RT-PCR procedures of Liang and Pardee (1992) were followed using the RNAimage kit (GenHunter Corp., Nashville, TN). Differential display reactions were performed using total RNA templates from the following sources: (1) 6- to 8-DAP dissected suspensors of globularstage embryos, (2) 6-DAP embryo-containing micropylar seed regions, (3) 6-DAP non-embryo-containing chalazal seed regions, (4) 6- to 8-DAP isolated globular-stage embryo propers, (5) leaves, (6) ovules, (7) 2-DAP whole seeds, and (8) 3-DAP whole seeds. Briefly, first-strand CDNAs were generated by reverse transcription of $200 \mathrm{ng}$ of total RNA using MMLV reverse transcriptase and an anchor/reverse primer (G primer, 5'-AAGCT 11 G-3'; C primer, 5'-AAGCT ${ }_{11} \mathrm{C}^{\prime}-3^{\prime}$ ). 
Aliquots of the first-strand cDNAs were used as templates for the PCR using combinations of forward and anchor/reverse primers in the presence of ${ }^{33} \mathrm{P}-\mathrm{dATP}$ and AmpliTaq polymerase (Perkin-Elmer, Branchburg, NJ). The forward primers used were H-AP49 (5'-AAGCTTTAGTCCA-3'), H-AP50 (5'-AAGCTTTGAGACT-3'), H-AP51 (5'AAGCTTCGAAATG-3'), H-AP52 (5'-AAGCTTGACCTाT-3'), H-AP53 (5'-AAGCTTCCTCTAT-3'), H-AP54 (5'-AAGCTITTGAGGT-3'), H-AP55 (5'-AAGCTTACGTTAG-3'), and H-AP56 (5'-AAGCTTATGAAGG-3'), where H-AP refers to the primers supplied by the RNAimage kit. The RT-PCR products were size fractionated on a $6 \%$ acrylamide gel and visualized by autoradiography.

We identified candidate suspensor-specific cDNAs as bands that were (1) $>200$ bp in size, (2) present at the same position in lanes containing cDNAs amplified from 6- to 8-DAP suspensor and micropylar region mRNAs, and (3) absent in lanes containing cDNAs amplified from chalazal region, embryo proper, and leaf mRNAs. Isolated cDNA fragments were amplified by PCR, cloned into the pCR2.1 vector (Invitrogen, San Diego, CA), and sequenced. cDNAs were designated with (1) a C or G, indicating the anchor/reverse primer used, (2) a twodigit number between 49 and 56, indicating the forward primer used, and (3) a one-digit number indicating the band position on the DD-RTPCR gel. For example, C541 represents a cDNA band that was amplified by a $\mathrm{C}$ anchor/reverse primer and an H-AP54 forward primer and that was in position 1 on the DD-RT-PCR gel.

\section{Gel Blot Analysis of PCR-Amplified Population cDNAs}

For prescreening of differential display cDNA clones, PCR-amplified cDNAs from different mRNA populations were generated according to the procedures of Kelly et al. (1990), with minor modifications. Suspensor (6 DAP), ovule, 2-DAP seed, 3-DAP seed, 6-DAP micropylar region, 6-DAP chalazal region, and leaf total RNAs were isolated. Firststrand CDNA was generated from $5 \mu \mathrm{g}$ of each RNA using MMLV reverse transcriptase and $50 \mathrm{ng} / \mu \mathrm{L}$ oligo $\left(\mathrm{dT}_{20}\right)$ as primer. The first-strand cDNAs were $3^{\prime}$ tailed with poly(dA) using terminal transferase. PCR amplifications were performed using the tailed first-strand CDNAs as templates and $2 \mu \mathrm{M} \mathrm{dT}_{20} \mathrm{dN}$ (where $\mathrm{dN}=\mathrm{dG}, \mathrm{dC}, \mathrm{dA}$, or $\mathrm{dT}$ ) as primer in $100 \mu \mathrm{L}$ containing $20 \mathrm{mM}$ Tris, $\mathrm{pH} 8.4,50 \mathrm{mM} \mathrm{KCl}, 1 \mathrm{mM} \mathrm{MgCl}$, and $0.2 \mu \mathrm{M}$ deoxynucleotide triphosphates at $94^{\circ} \mathrm{C}$ for $1 \mathrm{~min}, 42^{\circ} \mathrm{C}$ for $2 \mathrm{~min}$, and $72^{\circ} \mathrm{C}$ for $5 \mathrm{~min}$ for 30 cycles, followed by a 10-min extension at $72^{\circ} \mathrm{C}$. A $1-\mu \mathrm{L}$ aliquot from each reaction was used to perform another round of amplification using the same conditions. The reactions were extracted with phenol/chloroform and precipitated in ethanol. An aliquot equivalent to $1 \mu \mathrm{g}$ from each reaction was size fractionated on a $1 \%$ agarose gel, which then was used for DNA gel blot analysis according to the procedures of Sambrook et al. (1989).

\section{DNA Sequencing and Analysis}

DNA sequencing was performed according to the dideoxy sequencing procedures recommended by U.S. Biochemical Corp. (Cleveland, $\mathrm{OH}$ ). For genomic clones pG564g7.2.79 and pC541g2.1.5, unidirectional nested deletion sets were prepared using the Erasea-Base system (Promega). Compilation and analysis of sequences were performed using GCG (Genetics Computer Group, Madison, WI) and Gene Inspector (Textco, Inc., West Lebanon, NH) software. Open reading frames and exon-intron junctions were identified by GENSCAN (Burge and Karlin, 1997; http://ccr-081.mit.edu/GENSCAN. html). The G564 intron-exon junctions were confirmed by comparing the cDNA and gene sequences. Protein-sorting sequences were identified using PSORT (Nakai and Kanehisa, 1992; http://psort. nibb.ac.jp). DNA and protein sequence comparisons were performed using the National Center for Biotechnology Information GenBank BLAST programs (Altschul et al., 1997; http://www.ncbi.nlm.nih.gov). The complete C541 and G564 cDNA sequences were based on sequences from (1) DD-RT-PCR cDNA clones, (2) cDNA clones isolated from a 5- to 9-DAP seed cDNA library, and (3) cDNAs generated from 5 ' random amplification of cDNA ends (Chenchik et al., 1995).

\section{In Situ Hybridization}

In situ hybridization studies were performed as described by Cox and Goldberg (1988) and Yadegari et al. (1994) with minor modifications. Briefly, for scarlet runner bean, unfertilized ovules and individual seed (4 to 7 DAP) were harvested from pods, and seed were cut at their chalazal ends before fixing to enhance penetration of the fixative. For tobacco, seed up to 7 DAP were collected while still attached to the placenta. Older tobacco seed were separated from the placenta before collection. Tissues were fixed overnight at $4^{\circ} \mathrm{C}$ in $1 \%$ glutaraldehyde solution prepared in $0.1 \mathrm{M}$ phosphate buffer, pH 7.0, (Meyerowitz, 1987), dehydrated, cleared, and embedded in paraffin. Eight- to $10-\mu \mathrm{m}$ sections were hybridized to ${ }^{33} \mathrm{P}$-labeled sense or antisense RNA probes at a specific activity of 4 to $5 \times 10^{8} \mathrm{dpm} / \mu \mathrm{g}$. After hybridization and emulsion development, sections were stained with $0.05 \%$ toluidine blue in $0.05 \%$ borate solution. Photographs were taken using either bright-field or dark-field illumination with a compound microscope (Olympus BH2; Olympus Corp., Lake Success, NY). The photographs were digitized, adjusted for optimum silver grain resolution using the KPT-Equalizer program (Metacreations Corp., Carpinteria, CA), and assembled in Adobe Photoshop 5.0 (San Jose, CA).

\section{Light Microscopy}

\section{Bright-Field Microscopy}

Seeds and unfertilized ovules from scarlet runner bean were collected as described for in situ hybridization and fixed overnight in $5 \%$ glutaraldehyde, $0.1 \mathrm{M}$ phosphate buffer, $\mathrm{pH} 7.0$, and $0.01 \%$ Triton $\mathrm{X}-100$ at $4^{\circ} \mathrm{C}$. After dehydration, samples were embedded in Spurr's plastic resin (Spurr, 1969) (Polysciences, Warrington, PA). One-micrometer-thick sections were stained for 18 to $20 \mathrm{~min}$ at $42^{\circ} \mathrm{C}$ with $0.05 \%$ toluidine blue in $0.05 \%$ borate solution. Bright-field photographs were taken with Kodak Gold 100 film (ISO 100/21 ${ }^{\circ}$ using a compound microscope (Olympus BH-2).

\section{Whole-Mount Microscopy}

Dark-field photographs of seeds were taken using a dissecting microscope (Olympus SZH). Dark-field and bright-field photographs of dissected embryos were taken using a compound microscope (Olympus BH-2).

\section{Construction of the G564/GUS Marker Gene, Promoter Deletions, and Tobacco Plant Transformation}

A 21-kb G564 genomic clone was isolated from a scarlet runner bean $\lambda$ DASHII (Stratagene) genomic library by screening with a ${ }^{32} \mathrm{P}$-labeled 
G564 cDNA clone. A 7-kb genomic fragment was recloned in pBluescript KS + (Stratagene), generating plasmid pG564g7.2.79. A total of $4.8 \mathrm{~kb}$ of this plasmid was sequenced to confirm that the sequence of the coding region corresponded to that of the G564 cDNA clone. The entire G564g7.2.79 genomic clone was transferred into pGV1501AN, a pGV1500-derived plant transformation vector (DeBlaere et al., 1987).

The region in G564g7.2.79 surrounding the ATG start codon at position +57 relative to the transcription start site, as determined from the G564 cDNA sequence, was converted to an Sphl endonuclease restriction site by PCR using a T3 primer and a mutagenic oligonucleotide (5'-ATTGGACTGCATGCTTACGCTAGTCTGTGCAGAG-3'). A 4.2-kb G564 promoter region was cloned in the Sphl site upstream of the Escherichia coli GUS gene coding region (Jefferson et al., 1987) in pGEM5GUS, generating pG564GUS. After cloning, the G564 promoter region was resequenced. pGEM5GUS was constructed by inserting the GUS coding region and the Ti plasmid gene $73^{\prime}$ end from the TP12/ GUS gene (Drews et al., 1992) into the Ncol-Notl sites of pGEM5 (Promega). The G564/GUS gene was transferred to the pHYGA (hygromycin-resistant) plant transformation vector (Klucher et al., 1996).

For G564 promoter $5^{\prime}$ deletion analysis, a 6.9-kb Aatll (blunted)Notl pG564/GUS fragment containing the G564 promoter, the GUS coding region, and the Ti plasmid gene $73^{\prime}$ end was transferred to Ascl (blunted)-Notl-digested pGV1501AN, and a unidirectional G564 promoter nested $5^{\prime}$ deletion set was prepared using the Erase-a-Base system (Promega). The $5^{\prime}$ deletions were confirmed by sequence analysis to be at positions $-4018,-3879,-3806,-3605,-3009$, $-2427,-2267,-1907,-1838,-1736,-1485,-1364,-1007$, $-921,-662,-625,-546,-503,-488,-404,-326,-177$, $-153,-117$, and -22 . Tobacco plants were transformed and regenerated using the leaf disc procedure of Horsch et al. (1985). Each individual transformant was checked for T-DNA insertion by PCR analysis (Edwards et al., 1991), and the number of independent T-DNA insertions was determined by kanamycin-resistant segregation in $\mathrm{T} 1$ seeds after selfing.

\section{GUS Histochemical Assay}

Transgenic tobacco seeds were harvested at different stages of development (Barker et al., 1988). Embryos were dissected from seed in $50 \mathrm{mM}$ sodium phosphate, $\mathrm{pH}$ 7.0. Dissected embryos were incubated in GUS assay buffer ( $50 \mathrm{mM}$ sodium phosphate, $\mathrm{pH} 7.0,0.1 \%$ Triton X-100, $0.5 \mathrm{mM}$ ferricyanide, $0.5 \mathrm{mM}$ ferrocyanide, and $2 \mathrm{mM}$ 5 -bromo-4-chloro-3-indolyl- $\beta$-D-glucuronide) for $30 \mathrm{~min}$ to $16 \mathrm{hr}$ at room temperature (Jefferson et al., 1987). Embryos were photographed under bright-field or dark-field illumination using a compound $\mathrm{BH} 2$ Olympus microscope.

\section{Accession Numbers}

The GenBank accession numbers for C541, G563, G564, G564g7.2.79, and C541g2.1.5 are AF293403, AF293405, AF293404, AF325187, and AF325188, respectively.

\section{ACKNOWLEDGMENTS}

We acknowledge Prof. Walter Nagl for generously sharing his knowledge of scarlet runner bean biology and for suggesting Hammond's
Dwarf Red Flower as the best cultivar for our studies. We appreciate the help of Tatiana Tatarinova and the Bioinformatics Group at Ceres, Inc. (Malibu, CA), in the identification of conserved motifs in the G654 promoter. We thank Birgitta Sjostrand for providing help in the preparation of embryo sections and Margaret Kowalszyk for the preparation of the figures. We also thank Brandon Le for assistance with the transgenic tobacco plants, helping to prepare figures, and annotating the G564 promoter region. We are grateful to the members of our laboratory for helpful comments on the manuscript and generous help with different aspects of this project. K.W. was supported by TALENT stipend S86-142 from the Netherlands Organization for Scientific Research, by a Fulbright Fellowship, and by Human Frontier Science Program Organization Fellowship LT-413/ 96. This work was supported by Department of Energy and United States Department of Agriculture grants to R.B.G.

Received August 2, 2001; accepted September 7, 2001.

\section{REFERENCES}

Alpi, A., Lorenzi, R., Cionini, P.G., Bennici, A., and D'Amato, F. (1979). Identification of gibberellin $A_{1}$ in the embryo suspensor of Phaseolus coccineus. Planta 147, 225-228.

Altschul, S.F., Madden, T.L., Schaffer, A.A., Zhang, J., Zhang, Z., Miller, W., and Lipman, D.J. (1997). Gapped BLAST and PSIBLAST: A new generation of protein database search programs. Nucleic Acids Res. 25, 3389-3402.

Ausubel, F.M., Brent, R., Kingston, R.E., Moore, D.D., Seidman, J.G., Smith, J.A., and Struhl, K. (1992). Current Protocols in Molecular Biology. (New York: Green Publishing and Wiley Interscience).

Barker, S.J., Harada, J.J., and Goldberg, R.B. (1988). Cellular localization of soybean storage protein messenger RNA in transformed tobacco seeds. Proc. Natl. Acad. Sci. USA 85, 458-462.

Brady, T. (1973). Feulgen cytophotometric determination of the DNA content of the embryo proper and suspensor cells of Phaseolus coccineus. Cell Differ. 2, 65-75.

Burge, C., and Karlin, S. (1997). Prediction of complete gene structures in human genomic DNA. J. Mol. Biol. 268, 78-94.

Ceccarelli, N., Lorenzi, R., and Alpi, A. (1981). Gibberellin biosynthesis in Phaseolus coccineus suspensor. Z. Pflanzenphysiol. 102, 37-44.

Chenchik, A., Moqadam, F., and Siebert, P. (1995). Marathon cDNA amplification: A new method for cloning full-length cDNAs. Clontechniques 10, 5-8.

Clutter, M., Brady, T., Walbot, V., and Sussex, I. (1974). Macromolecular synthesis during plant embryogenesis: Cellular rates of RNA synthesis in diploid and polyploid cells in bean embryo. J. Cell Biol. 63, 1097-1102.

Cox, K.H., and Goldberg, R.B. (1988). Analysis of plant gene expression. In Plant Molecular Biology: A Practical Approach, C.H. Shaw, ed (Oxford, UK: IRL Press), pp. 1-34.

Davidson, E.H., Cameron, R.A., and Ransick, A. (1998). Specification of cell fate in the sea urchin embryo: Summary and some proposed mechanisms. Development 125, 3269-3290. 
DeBlaere, R., Reynaerts, A., Hofte, H., Hernalsteens, J.-P., Leemans, J., and Van Montagu, M. (1987). Vectors for cloning in plant cells. Methods Enzymol. 153, 277-292.

De Paiva, G. (1994). Transcriptional Regulation of Seed Protein Genes. Ph.D. Dissertation (Los Angeles: University of California).

Dornelas, M.C., Wittich, P., von Recklinghausen, I., van Lammeren, A., and Kreis, M. (1999). Characterization of three novel members of the Arabidopsis SHAGGY-related protein kinase (ASK) multigene family. Plant Mol. Biol. 39, 137-147.

Drews, G.N., Beals, T.P., Bui, A.Q., and Goldberg, R.B. (1992). Regional and cell-specific gene expression patterns during petal development. Plant Cell 4, 1383-1404.

Edwards, K., Johnstone, C., and Thompson, C. (1991). A simple and rapid method for the preparation of plant genomic DNA for PCR analysis. Nucleic Acids Res. 19, 1349.

Feinberg, A.P., and Vogelstein, B. (1984). A technique for radiolabelling DNA fragments to high specific activity. Anal. Biochem. 137, 266-267.

Goldberg, R.B., Barker, S.J., and Perez Grau, L. (1989). Regulation of gene expression during plant embryogenesis. Cell 56, 149-160.

Goldberg, R.B., De Paiva, G., and Yadegari, R. (1994). Plant embryogenesis: Zygote to seed. Science 266, 605-614.

Horsch, R.B., Fry, J., Hoffman, N., Eichholtz, D., Rogers, S., and Fraley, R. (1985). A simple and general method for transferring genes into plants. Science 227, 1229-1231.

Ingram, G.C., Boisnard Lorig, C., Dumas, C., and Rogowsky, P.M. (2000). Expression patterns of genes encoding HD-ZipIV homeodomain proteins define specific domains in maize embryos and meristems. Plant J. 22, 401-414.

Jefferson, R.A., Kavanagh, T.A., and Bevan, M.W. (1987). GUS fusions: $\beta$-Glucuronidase as a sensitive and versatile gene fusion marker in higher plants. EMBO J. 6, 3901-3907.

Jofuku, K.D., and Goldberg, R.B. (1989). Kunitz trypsin inhibitor genes are differentially expressed during the soybean life cycle and in transformed tobacco plants. Plant Cell 1, 1079-1093.

Jofuku, K.D., Schipper, R.D., and Goldberg, R.B. (1989). A frameshift mutation prevents Kunitz trypsin inhibitor mRNA accumulation in soybean embryos. Plant Cell 1, 427-435.

Johri, B.M. (1984). Embryology of Angiosperms. (Berlin: SpringerVerlag).

Kaplan, D.R., and Cooke, T.J. (1997). Fundamental concepts in the embryogenesis of dicotyledons: A morphological interpretation of embryo mutants. Plant Cell 9, 1903-1919.

Kelly, A.J., Zagotta, M.T., White, R.A., Chang, C., and MeeksWagner, D.R. (1990). Identification of genes expressed in the tobacco shoot apex during floral transition. Plant Cell 2, 963-972.

Klucher, K.M., Chow, H., Reiser, L., and Fischer, R.L. (1996). The AINTEGUMENTA gene of Arabidopsis required for ovule and female gametophyte development is related to the floral homeotic gene APETALA2. Plant Cell 8, 137-153.

Kropf, D.L. (1997). Induction of polarity in fucoid zygotes. Plant Cell 9, 1011-1020.

Lall, S., Francis-Lang, H., Flament, A., Norvell, A., Schupbach, T., and Ish-Horowicz, D. (1999). Squid hnRNP protein promotes apical cytoplasmic transport and localization of Drosophila pairrule transcripts. Cell 98, 171-180.
Laux, T., and Jurgens, G. (1997). Embryogenesis: A new start on life. Plant Cell 9, 898-1000.

Liang, P., and Pardee, A.B. (1992). Differential display of eukaryotic messenger RNA by means of the polymerase chain reaction. Science 257, 967-971.

Lu, P., Porat, R., Nadeau, J.A., and O'Neill, S.D. (1996). Identification of a meristem L1 layer-specific gene in Arabidopsis that is expressed during embryonic pattern formation and defines a new class of homeobox genes. Plant Cell 12, 2155-2168.

Mansfield, S.G., and Briarty, L.G. (1991). Early embryogenesis in Arabidopsis thaliana. II. The developing embryo. Can. J. Bot. 69, 461-476.

McConnell, J.R., Emery, J., Eshed, Y., Bao, N., Bowman, J.L., and Barton, M.K. (2001). Role of PHABULOSA and PHAVOLUTA in determining radial patterning in shoots. Nature 411, 709-712.

Meyerowitz, E.M. (1987). In situ hybridization to RNA in plant tissue. Plant Mol. Biol. Rep. 5, 242-250.

Miller, S.S., Bowman, L.A.A., Gijzen, M., and Miki, B.L.A. (1999). Early development of the seed coat of soybean (Glycine max). Ann. Bot. 84, 297-304.

Nagl, W. (1974). The Phaseolus suspensor and its polytene chromosome. Z. Pflanzenphysiol. 73, 1-44.

Nagl, W. (1990). Translocation of putrescine in the ovule, suspensor, and embryo of Phaseolus coccineus. J. Plant Physiol. 136, 587-591.

Nakai, K., and Kanehisa, M. (1992). A knowledge base for predicting protein localization sites in eukaryotic cells. Genomics 14, 897-911.

Natesh, S., and Rau, M.A. (1984). The embryo. In Embryology of Angiosperms, B.M. Johri, ed (Berlin: Springer-Verlag), pp. 377-444.

Quatrano, R. (1997). Cortical asymmetries direct the establishment of cell polarity and the plane of cell division in the Fucus embryo. Cold Spring Harbor Symp. Quant. Biol. 57, 65-70.

Raghavan, V. (1986). Embryogenesis in Angiosperms: A Developmental and Experimental Study. (Cambridge, UK: Cambridge University Press).

Sambrook, J., Fritsch, E.F., and Maniatis, T. (1989). Molecular Cloning: A Laboratory Manual. (Cold Spring Harbor, NY: Cold Spring Harbor Laboratory Press).

Schnepf, E., and Nagl, W. (1970). Ueber einige Strukturbesonderheiten der Suspensorzellen von Phaseolus vulgaris. Protoplasma 69, 133-143.

Schwartz, B.W., Vernon, D.A., and Meinke, D.W. (1997). Development of the suspensor: Differentiation, communication and programmed cell death during plant embryogenesis. In Cellular and Molecular Biology of Plant Seed Development, B. Vasil, ed (Dordrecht, The Netherlands: Kluwer Academic Publishers), pp. 53-72.

Sen, J., Goltz, J.S., Stevens, L., and Stein, D. (1998). Spatially restricted expression of pipe in the Drosophila egg chamber defines embryonic dorsal-ventral polarity. Cell 95, 471-481.

Showalter, A.M. (1993). Structure and function of plant cell wall proteins. Plant Cell 5, 9-23.

Soueges, R. (1920). Embryogenie des Solanacees: Developpement de l'embryon chez les Nicotiana. C. R. Acad. Sci. Paris 170, 11251127.

Spurr, A.R. (1969). A low-viscosity epoxy resin embedding medium for electron microscopy. J. Ultrastruct. Res. 26, 31-43. 
Sussex, I., Clutter, M., Walbot, V., and Brady, T. (1973). Biosynthetic activity of the suspensor of Phaseolus coccineus. Caryologia 25, 261-272.

van Den Berg, C., Weisbeek, P., and Scheres, B. (1998). Cell fate and cell differentiation status in the Arabidopsis root. Planta 205, 483-491.

Vodkin, L.O., Rhodes, P.R., and Goldberg, R.B. (1983). A lectin gene insertion has the structural features of a transposable element. Cell 34, 1023-1031.

Voss, R., Schumann, K., and Nagl, W. (1992). Phytohemagglutinin gene expression during seed development of the runner bean, Phaseolus coccineus. Plant Mol. Biol. 20, 781-790.

Walbot, V., Brady, T., Clutter, M., and Sussex, I. (1972a). Macromolecular synthesis during plant embryogeny: Rates of RNA synthesis in Phaseolus coccineus embryos and suspensors. Dev. Biol. 29, 104-111.

Walbot, V., Clutter, M., and Sussex, I. (1972b). Reproductive development and embryogeny in Phaseolus. Phytomorphology 22, 59-68.

Walthall, E.D., and Brady, T. (1986). The effect of the suspensor and gibberellic acid on Phaseolus vulgaris embryo protein synthesis. Cell Differ. 18, 37-44.

West, M.A.L., and Harada, J.J. (1993). Embryogenesis in higher plants: An overview. Plant Cell 5, 1361-1369.

Willemse, M.T.M., and van Went, J.L. (1984). The female gametophyte. In Embryology of Angiosperms, B.M. Johri, ed (Berlin: Springer-Verlag), pp. 159-196.
Winkler, R.G., Frank, M.R., Galbraith, D.W., Feyereisen, R., and Feldmann, K.A. (1998). Systematic reverse genetics of transferDNA-tagged lines of Arabidopsis: Isolation of mutations in the cytochrome P450 gene superfamily. Plant Physiol. 118, 743-749.

Yadegari, R. (1996). Regional Specification and Cellular Differentiation during Early Plant Embryogenesis. Ph.D. Dissertation (Los Angeles: University of California).

Yadegari, R., De Paiva, G., Laux, T., Koltunow, A.M., Apuya, N., Zimmerman, J.L., Fischer, R.L., Harada, J.J., and Goldberg, R.B. (1994). Cell differentiation and morphogenesis are uncoupled in Arabidopsis raspberry embryos. Plant Cell 6, 1713-1729.

Yeung, E.C. (1980). Embryogeny of Phaseolus: The role of the suspensor. Z. Pflanzenphysiol. 96, 17-28.

Yeung, E.C., and Clutter, M. (1978). Embryogeny in Phaseolus coccineus: Growth and microanatomy. Protoplasma 94, 19-40.

Yeung, E.C., and Clutter, M. (1979). Embryogeny in Phaseolus coccineus: The ultrastructure and development of the suspensor. Can. J. Bot. 57, 120-136.

Yeung, E.C., and Meinke, D.W. (1993). Embryogenesis in angiosperms: Development of the suspensor. Plant Cell 5, 1371-1381.

Yeung, E.C., and Sussex, I. (1979). Embryogeny of Phaseolus coccineus: The suspensor and the growth of the embryo-proper in vitro. Z. Pflanzenphysiol. 91, 423-433.

Yisreali, J.K., Sokol, S., and Melton, D.A. (1990). A two-step model for the localization of maternal mRNA in Xenopus oocytes: Involvement of microtubules and microfilaments in the translocation and anchoring of Vg1 mRNA. Development 108, 289-298. 